\title{
EVALUATION OF THE POTENTIAL OF BIODIESEL 3G: CLOSED PHOTOBIOREACTORS
}

\author{
Lidiane Machado ${ }^{1}$, Erika Francisco ${ }^{1}$, Leila Queiroz Zepka ${ }^{1}$, Maria Isabel \\ Queiroz $^{2}$, Telma Teixeira Franco ${ }^{3}$, Eduardo Jacob-Lopes 1 \\ 1 Food Science and Technology Department, Federal University of Santa Maria \\ (UFSM), 97105-900, Santa Maria- RS, Brazil \\ 2 School of Chemistry and Food, Federal University of Rio Grande (FURG), 96201- \\ 900, Rio Grande- RS, Brazil \\ ${ }^{3}$ School of Chemical Engineering, State University of Campinas (UNICAMP), 97105- \\ 700, Campinas-SP, Brazil. \\ E-mail: jacoblopes@pq.cnpq.br
}

\begin{abstract}
- currently, microalgae have gained a lot of attention for their potential to produce lipids for biofuel production. For these applications, microalgae are cultivated in several different systems and the lipid productivity has been the main criteria for process selection. This study evaluates the potential of two differents microalgae (Aphanothece microscopica Nägeli and Chlorella vulgaris) cultivated photosynthetically in a bubble column photobioreactor for production of third generation biodiesel (3G). Results indicate that Chlorella vulgaris was the best strain to use as a feedstock for biodiesel production. A biomass productivity of $20 \mathrm{mg}$ $\mathrm{L}^{-1} \mathrm{~h}^{-1}$, a lipid content of $27 \%$ and a lipid productivity of $5 \mathrm{mg} \mathrm{L}^{-1} \mathrm{~h}^{-1}$ were obtained. For Aphanothece microscopica Nägeli a larger amount of biomass was produced ( $\left.31 \mathrm{mg} \mathrm{L}^{-1} \mathrm{~h}^{-1}\right)$. However, the resulting lipid content and lipid productivity were lower ( $8 \%$ and $2.5 \mathrm{mg} \mathrm{L}^{-1} \mathrm{~h}^{-1}$, respectively).
\end{abstract}

\section{INTRODUCTION}

Nowadays, the microalgae have won a relevance for their ability to produce lipids, according Slegers et al. (2013) some microalgae are known to produce fairly high amounts of lipids and can be used by means of bioprocessing to produce alternative oils for biofuels manufacture. Ratledge (2005) report the possibility of oil accumulation through the manipulation of environmental culture conditions has a great potential in SCO (single-cell oils) production.

Process engineering to produce microalgae biodiesel is an emergent area for industrial practice with great promise for partially replacing the obtention of petrodiesel and biodiesel from oil crops. According to Sheehan et al. (1998), if microalgal oil production could be scaled up industrially, fewer than 6 million hectares, amounting to less $0.4 \%$ of arable land available, would be necessary worldwide to meet current fuel demands.

Furthermore, as shown by William and Laurens (2010) the microalgae-based oil has being identified as third-generation biofuel with several advantages over terrestrial 
crops such as less land use, potential cultivation in non-fertile locations, faster growth and with special emphasis in the high lipid to biodiesel yield.

Besides, as cited by Chisti (2007) the plant growth suffers from cyclic changes due to day/night times and seasons conditions. The ratio of chemical energy content of biomass versus incoming solar radiation is limited for terrestrial crops, resulting in energy efficiencies generally below $1 \%$ in temperature climates. Based on the current studies, the expected photoconversion efficiency can reach up to $5 \%$ for microalgae biomass.

Nonetheless, in order to make microalgal biodiesel competitive, single-cell oil productivity evaluation is required under different process conditions. However, technoeconomic barriers have limited the implementation of this technology on a commercial scale.

The aim of this study was evaluate microalgae as a feedstock for biodiesel production, the focus was on evaluates the potential of two differents microalgae (Aphanothece microscopica Nägeli and Chlorella vulgaris) cultivated photosynthetically in a bubble column photobioreactor for production of third generation biodiesel $(3 \mathrm{G})$.

\section{MATERIAL AND METHODS}

Stock cultures were propagated and maintained in a synthetic medium under incubation conditions of $25^{\circ} \mathrm{C}$, a photon flux density of $15 \mu \mathrm{molm}^{-2} \mathrm{~s}^{-1}$ and a photoperiod of $12 \mathrm{~h}$.

Measurements were made in a bubble column photobioreactor. The system was built of $4 \mathrm{~mm}$ thick glass and had an internal diameter of $7.5 \mathrm{~cm}$, a height of $75 \mathrm{~cm}$ and a nominal working volume of $3.0 \mathrm{~L}$. The dispersion system for the reactor consisted of a $1.5 \mathrm{~cm}$ diameter air diffuser located in the center of the column. The reactor was continuously illuminated with sixteen 20-W fluorescent lamps (daylight-type), connected in parallel, located in a photoperiod chamber. The duration of the light cycle was controlled by a timer. Airflow into the photobioreactor was provided via filtered air and pure $\mathrm{CO} 2$ cylinders through Teflon tubing. The $\mathrm{CO} 2$-air mixture was adjusted to achieve the desired concentration of carbon dioxide in the air stream through three rotameters, which measured the flow rates of the carbon dioxide, the air and the mixture of gases, respectively.

The experiments were carried out in bioreactors operating in na intermittent regime, fed with $3.0 \mathrm{~L}$ of culture médium The experimental conditions were as follows: an initial cell concentration of $0.1 \mathrm{~g} \mathrm{~L}-1$, an isothermal reactor operating at a temperature of $30^{\circ} \mathrm{C}$, a photon flux density of $150 \mu \mathrm{molm}^{-2} \mathrm{~s}^{-1}$, and continuous aeration of $1 \mathrm{VVM}$ (volume of air per volume of culture per minute) with the injection of air enriched with 15\% carbon dioxide. The light cycle evaluated was $24: 0$ (day : night). The cell density, was monitored every $12 \mathrm{~h}$ during the growth phase of the microorganisms and the lipid content of the biomass at the end of the cultivations. The tests were carried out in duplicate and the kinetic data referred to the mean of four repetitions. 
The cell density was gravimetrically evaluated by filtering a known volume of culture medium through a $0.45 \mu \mathrm{m}$ filter and drying at $60{ }^{\circ} \mathrm{C}$ for $24 \mathrm{~h}$ and the lipid fraction was extracted from the biomass by the Bligh and Dyer (1959) method.

\section{RESULTS AND DISCUSSION}

\subsection{BIOMASS AND OIL PRODUCTION}

The Chlorella species have been preferred over other microalgae by many researchers (Bhatnagar et al., 2010; Chu et al., 2009), especially because they are usually isolated from sewage treatment plants and can be considered as autochthonous species. In addition, Aphanothece microscopica Nägeli has been selected by some researchers because, in accordance with Jacob-Lopes et al. (2008) they are a cyanobacteria that has high growth rates in photosynthetic and heterotrophic cultivation.

Therefore, the lipid production potential of each microalgae was carefully monitored in batch photobioreactor. The growth data obtained in these experiments are shown in Table 1.

Table 1. Lipid composition and lipid productivities at different species

\begin{tabular}{lccc}
\hline Microalgae & $\begin{array}{c}\text { Lipid } \\
(\% \mathbf{w t})\end{array}$ & $\begin{array}{c}\mathbf{P}_{\mathbf{X}} \\
\left(\mathbf{m g ~ L}^{-\mathbf{1}} \mathbf{h}^{\mathbf{- 1}}\right)\end{array}$ & $\begin{array}{c}\mathbf{P}_{\mathbf{L}} \\
\left(\mathbf{m g ~ L}^{-\mathbf{1}} \mathbf{h}^{-\mathbf{1}}\right)\end{array}$ \\
\hline Chlorella & 27.0 & 20.1 & 5.3 \\
Aphanothece & 8.0 & 31.4 & 2.5 \\
\hline Lipid, lipid content; $\mathrm{P}_{\mathrm{X}}$, biomass productivity; $\mathrm{P}_{\mathrm{L}}$, lipid productivity.
\end{tabular}

The best biomass producer was the cyanobacterium A. microscopica Nägeli $\left(\mathrm{P}_{\mathrm{X}}=31.4 \mathrm{mg} \mathrm{L}^{-1} \mathrm{~h}^{-\mathbf{1}}\right)$; however, its lipid content was low (8\% of the dry biomass) and thus its lipid productivity $\left(\mathrm{P}_{\mathrm{L}}\right)$ was also low $\left(2.5 \mathrm{mg} \mathrm{L}^{-1} \mathrm{~h}^{-1}\right)$.

In results shown by Mata et al. (2010) and Khan et al. (2009) the lipid content of strains tested varied from (4\% Spirulina maxima to $77 \%$ Schizochytrium $s p$.), in this study the best producer, $C$. vulgaris $(27 \%)$, also had the highest lipid productivity (5.3 $\left.\mathrm{mg} \mathrm{L}^{-1} \mathrm{~h}^{-1}\right)$, although had a low biomass productivity $\left(20.1 \mathrm{mg} \mathrm{L}^{-1} \mathrm{~h}^{-1}\right)$.

In general, productivity and lipid content were inversely related, Ratledge and Cohen (2008) have explained this fact by the high metabolic cost of lipid biosynthesis, in this present work lipid-rich specie showed lower biomass productivity, confirming that high biomass productivity and high lipid content are mutually exclusive. The best lipid producer is the strain showing the best combination of biomass productivity and lipid content. In accordance with showed in the Figure 2. 


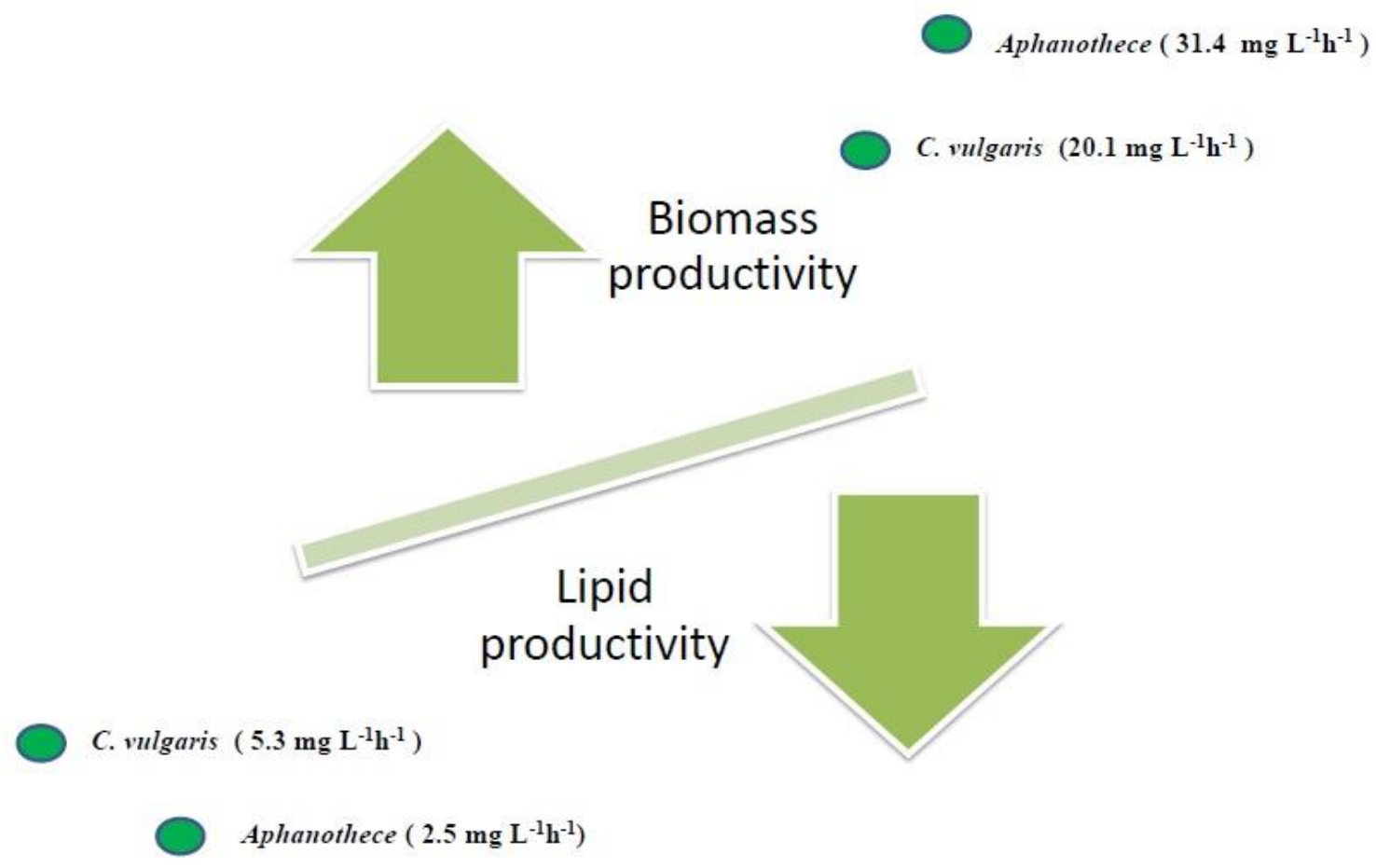

FIGURE 2. Biomass productivity vs. lipid productivity.

\subsection{MICROALGAE AS A POTENTIAL SOURCE OF BIODIESEL}

Chisti (2007) explain that the cultivation of microalgae productivity features significantly exceeding oilseed plants and provides a greater reduction in area, thus obtaining an increase in biomass productivity and lipid.

The microalgae Chlorella Vulgaris can potentially reach lipid content of $27 \%$, whereas the soybean has a percentage of only $20 \%$ compared to the same period of time (120 days). The cultivation of soybean has an annual production cycle of 120 days / year. Therefore, in such a competitive sector as biodiesel, the possibility of expanding this cycle is a major advantage, which is an exclusive opportunity of bioprocesses.

Besides, one of the ways to increase productivity of a biotechnological process is to convert it into a continuous process. It can be reached by using a reactor operated continuously (CSTR). In this case, the equivalence of soybean lipid productivity would be achieved with a 1 Liter CSTR.

Considering the space needed for soybean and microalgae in order to be obtained the same lipid productivity, the area occupied by microalgae will be much less than that occupied by traditional crops, in accordance with Figueiredo (2011) below $6 \%$, hence the great advantage of microalgae. In this study, it was shown that the lipid production was $5.3 \mathrm{mg} \mathrm{L}^{-1} \mathrm{~h}^{-1}$ (obtained through Clorella vulgaris). Taking the average yield reported by CONAB (2014) for soybean oil was around $19.1 \mathrm{mg}_{\text {lipid }} / \mathrm{m}^{2} . \mathrm{h}$ It shows that equivalence production from this microalgae is easily achieved using a bioreactor 
operated continuously (CSTR) for $3,5 \mathrm{~L} / \mathrm{m}^{2}$. In this work, relevance is placed on the fact that microalgae can be planted in small areas.

However, application on an industrial level in continuous system production requires problem solving in engineering and microbiology as the selection of the support and the kind of microalgae, the reactor model, the risk of contamination, among others, which together with the effect of the physiology of microalgae makes it difficult to predict the qualitative and quantitative aspects of biomass produced. Thus, the production of material for biodiesel by microalgae, remains a big challenge and simultaneously a great opportunity for the biofuels sector, may become a reality in the coming years in modern biorefineries.

\section{CONCLUSIONS}

Microalgae have emerged as one the most promising feedstocks for biodiesel production. According to observation in this study, Clorella Vulgaris was the microalgae with the greatest potential for SCO exploitation among the strains tested (lipid productivity of $5.3 \mathrm{mg} \mathrm{L}^{-1} \mathrm{~h}^{-1}$ ). Demonstrating the potential of this microalgae as matrix for oil production for biofuels.

\section{REFERENCES}

Amaro HM, Guedes AC, Malcata FX. Advances and perspectives in using microalgae to produce biodiesel. Appl Energy 2011;88:3402-10.

Bhatnagar A, Bhatnagar M, Chinnasamy S, Das K. Chlorella minutissima - a promising fuel alga for cultivation in municipal wastewaters. Appl Biochem Biotechnol 2010;161:523-36.

Brennan L, Owende P. Biofuels from microalgae - a review of technologies for production, processing, and extractions of biofuels and co-products. Renew Sustain Energy Rev 2010;14:557-77.

Chisti Y, Biodiesel from microalgae. Biotechnol Adv 25:294-306 (2007).

Chu WL, See YC, Phang SM. Use of immobilised Chlorella vulgaris for the removal of colour from textile dyes. J Appl Phycol 2009;21:641-8.

Jacob-Lopes E, Lacerda LMCF and Franco TT. Biomass production and carbon dioxide fixation by Aphanothece microscopica Nägeli in a bubble column photobioreactor. Biochem Eng J. 40: 27-34 (2008).

Khan, S. A.; Rashmi; Hussain, M. Z.; Prasad, S.; Banerjee, U. C.; Renew. Sust. Energ. Rev. 2009, 13, 2361.

Mata, T. M.; Martins, A. A.; Caetano, N. S.; Renew. Sust. Energ. Rev. 2010, 14, 217.

R, Aden A, Pienkos PT. Techno-economic analysis of autotrophicmicroalgae for fuel production. Appl Energy 2011;88:3524-31.

Ratledge C, Cohen Z. Microbial and algal oils: do they have a future for biodiesel or as commodity oils. Lipid Technol 2008;20:155-60. 
Ratledge C., Single cell oils for the $21^{\text {st }}$ century. In: Cohen Z, Ratledge C, editors. Single cell oils. AOCS Press; 2005.

Sheehan J, Dunahay T, Benemann J and Roessler P, A look Back At the Us Department of Energy's Aquatic Species Program: Biodiesel from Algae. US report NREL/TP- 580-24190. National Renewable Energy Laboratory, Golden, CO, p. 323 (1998).

Singh J, Gu S. Commercialization potential of microalgae for biofuels production. Renew Sustain Energy Rev 2010;14:2596-610.

Slegers P.M et al., Scenario evaluation of open pond microalgae production. Algal Research (2013).

Williams, P.J.B., Laurens, L.M.L., 2010. Microalgae as biodiesel and biomass feedstocks: review and analysis of the biochemistry, energetics and economics. Energy \& Environmental Science 3 (5), 554-590. 